\title{
Transcriptomic and Histopathological Effects of Bifenthrin to the Brain of Juvenile Rainbow Trout (Oncorhynchus mykiss)
}

\author{
Jason T. Magnuson ${ }^{1, *(\mathbb{D}}$, Kara E. Huff Hartz ${ }^{2}$, Corie A. Fulton ${ }^{2}$, Michael J. Lydy ${ }^{2}{ }^{(\mathbb{O}}$ and Daniel Schlenk ${ }^{1,3}$ \\ 1 Department of Environmental Sciences, University of California, Riverside, 2460A Geology, \\ Riverside, CA 92521, USA; daniel.schlenk@ucr.edu \\ 2 Department of Zoology, Center for Fisheries, Aquaculture and Aquatic Sciences, Southern Illinois University, \\ Carbondale, IL 62901, USA; khuffhar@siu.edu (K.E.H.H.); corie.fulton@gmail.com (C.A.F.); \\ mlydy@siu.edu (M.J.L.) \\ 3 Institute of Environmental Health, College of Environmental and Resource Sciences, Zhejiang University, \\ Hangzhou 310058, China \\ * Correspondence: jason.magnuson@ucr.edu
}

check for updates

Citation: Magnuson, J.T.; Huff Hartz, K.E.; Fulton, C.A.; Lydy, M.J.; Schlenk, D. Transcriptomic and

Histopathological Effects of

Bifenthrin to the Brain of Juvenile Rainbow Trout (Oncorhynchus mykiss). Toxics 2021, 9, 48. https://doi.org/ $10.3390 /$ toxics 9030048

Academic Editors: Susanne M. Brander and Alvine C. Mehinto

Received: 15 February 2021

Accepted: 4 March 2021

Published: 5 March 2021

Publisher's Note: MDPI stays neutral with regard to jurisdictional claims in published maps and institutional affiliations.

\begin{abstract}
The increased global use of pyrethroids raises concern for non-target aquatic species. Bifenthrin, among the most predominantly detected pyrethroids in the environment, is frequently measured in water samples above concentrations reported to induce neuroendocrine and neurotoxic effects to several threatened and endangered fish species, such as the Chinook salmon and steelhead trout. To better characterize the neurotoxic effect of bifenthrin to salmonids, rainbow trout were treated with environmentally relevant concentrations of bifenthrin (15 and $30 \mathrm{ng} / \mathrm{L})$ for two weeks and assessed for changes in transcriptomic profiles and histopathological alterations. The top bioinformatic pathways predicted to be impaired in bifenthrin-exposed trout were involved in gonadotropin releasing hormone signaling, the dysregulation of iron homeostasis, reduced extracellular matrix stability and adhesion, and cell death. Subsequent histopathological analysis showed a significant increase in TUNEL positive cells in the cerebellum and optic tectum of bifenthrin-treated trout, relative to controls $(p<0.05)$. These findings suggest that low, $\mathrm{ng} / \mathrm{L}$ concentrations of bifenthrin are capable of dysregulating proper neuroendocrine function, impair the structural integrity of the extracellular matrix and cell signaling pathways in the brain, and induce apoptosis in neurons of juvenile salmonids following bifenthrin treatment, which is consistent with metabolomic profiles demonstrating a common target and mechanism.
\end{abstract}

Keywords: pyrethroid; bifenthrin; salmonid; transcriptomics; apoptosis

\section{Introduction}

The widespread application of pyrethroid insecticides for agricultural and urban use within the last 20 years, largely in response to the phase-out of organochlorine and organophosphate insecticides [1], has raised concern for non-target aquatic species. This shift has increased the amount of pyrethroid active compounds applied worldwide, exceeding 8000 tons in 2014 [2]. Pyrethroids are currently ranked as the third most applied insecticide group [3], with China and the United States represented as the top global producers and users of pyrethroids [4]. Though the mammalian toxicity of pyrethroids is lower than organochlorines and organophosphates [5], the overall environmental risk of pyrethroids has been suggested to be greater than these older-generation insecticides [6]. Pyrethroids are comprised of Type I and Type II chemical classes. Type I pyrethroids include permethrin, allethrin, resmethrin, and bifenthrin and lack an $\alpha$-cyano group, whereas type II classes include cypermethrin, deltamethrin, esfenvalerate, and lambda-cyhalothrin and carry an $\alpha$-cyano moiety.

The type I pyrethroid, bifenthrin, was the most frequently detected pyrethroid in sediment samples worldwide [3]. Bifenthrin was present in $78 \%$ of sediment samples 
collected from the United States, Australia, and China [3], and was recently detected in 77\% of samples collected throughout California [7], with measured concentrations among the highest in the United States, $744 \mathrm{ng} / \mathrm{g}$ dry weight $[3,8]$. Similarly, bifenthrin was the most frequently detected pyrethroid in water samples in California, being detected in up to $79 \%$ of samples within the Sacramento-San Joaquin Delta $[9,10]$, with the highest frequency and concentration measured from urban runoff areas (106 ng/L) [10] and following stormwater runoff events (133 ng/L) [9]. Concentrations of bifenthrin have also been measured above $3 \mu \mathrm{g} / \mathrm{L}$ within the Delta [11].

The Sacramento-San Joaquin Delta is an important spawning ground for endangered and threatened fish species, such as the steelhead trout (Oncorhynchus mykiss) and Chinook salmon (Oncorhynchus tshawytscha), which are found within the Sacramento and San Joaquin Rivers and associated tributaries. However, over the last few decades, large decreases in several pelagic fish species, known as the pelagic organism decline (POD), have occurred within the Delta. These decreases are most likely due to multiple stressors, such as flow regulations, habitat alteration, invasive species, human-made structures, overfishing, and increases in runoff pollution [12,13]. Subsequently, the increased use of pyrethroid insecticides, such as bifenthrin, since the mid-2000's, coincided with decreased migratory returns in these spawning waters and may also be contributing to the POD [14-18]. Concentrations of bifenthrin in water samples collected from the Delta have been detected above acute and chronic benchmark values for several aquatic invertebrate and fish species $(>1.3$ and $>40 \mathrm{ng} / \mathrm{L}$, respectively) $[10,19]$, and well above levels reported to dysregulate neuroendocrine function $(\leq 1.5 \mu \mathrm{g} / \mathrm{L})$ [20-22] and induce neurotoxicity in salmonids ( $\leq 120 \mathrm{ng} / \mathrm{L})[23,24]$.

The primary mode of action for bifenthrin is binding to and disrupting voltagegated $\mathrm{Na}^{+}$channels, impairing neuronal function by altering the release of neurotransmitters [25-27]. Bifenthrin is a known endocrine disruptor in fish [28-32], dysregulating the hypothalamic-pituitary-gonadal (HPG) and hypothalamic-pituitary-thyroid (HPT) axis in salmonids by acting upon the dopaminergic pathway [20-22,31]. Bifenthrin is also capable of dysregulating $\mathrm{Ca}^{2+}$ homeostasis by impairing signaling molecules, as recently reported in inland silversides (Menidia beryllina) and zebrafish (Danio rerio) following bifenthrin treatment $(<10 \mathrm{ng} / \mathrm{L})[33,34]$. Additionally, by utilizing a non-targeted metabolomics approach, we recently reported that bifenthrin can induce neuronal apoptotic, necrotic, and inflammatory responses in the brains of Chinook salmon (Oncorhynchus tshawytscha) [24] and steelhead trout (Oncorhynchus mykiss) [23] following exposure to $\leq 1.5 \mu \mathrm{g} / \mathrm{L}$ and $\leq 120 \mathrm{ng} / \mathrm{L}$ bifenthrin, respectively.

The use of transcriptomic profiling to better understand the underlying effects of contaminants found in aquatic systems has increased in the last decade due to reduced cost, high-through-put capabilities, and comparability between species and contaminant effects. RNA sequencing, combined with downstream bioinformatic functional annotation software, provides a platform for relating gene expression changes to predicted ontological changes, diseases, and associated modes of actions driving these responses. The goal of the current study was to characterize the neurotoxic effect of bifenthrin to a salmonid species, rainbow trout, through the use of transcriptomics and relate these molecular-level effects to histopathological changes in the brain. We hypothesized that there would be a dose dependent relationship between transcriptomic level changes and histological insult that were due to alterations in genes involved with reactive oxygen species production, inflammatory and oxidative stress responses, and apoptosis, as metabolites involved in these pathways were previously dysregulated in steelhead trout and Chinook salmon exposed to bifenthrin.

\section{Materials and Methods}

\subsection{Exposure Treatments}

Juvenile rainbow trout used for this study $(n=24)$ were obtained from Jess Ranch Lakes Fish Hatchery (Apple Valley, CA, USA) and were maintained in a $530 \mathrm{~L}$ flow-through Living Stream System (LS-700; Frigid Units, Toledo, OH, USA) at $12{ }^{\circ} \mathrm{C}$ for three months 
under a 14:10 h light:dark photoperiod. During this period, trout were fed Oncor Fry pellets (Skretting, Tooele, UT, USA) ad libitum daily. Individual rainbow trout were randomly transferred into $8 \mathrm{~L}$ glass aquaria and allowed to acclimate to the new tanks for 3 days before experimentation, as previously described [23]. Fish were fed Oncor Fry trout pellets every other day during exposures, which equated to $1 \%$ of their body weight. Rainbow trout (mean length $=21.5 \pm 1.5 \mathrm{~cm}$; mean weight $=78.68 \pm 13.90 \mathrm{~g}$ ) were exposed for a two-week period to one of three treatments: control ( $0.01 \%$ ethanol), 15 , or $30 \mathrm{ng} / \mathrm{L}$ bifenthrin (purity $>96 \%$, racemic mix of isomers; Chem Service, West Chester, PA, USA), which represent environmentally relevant concentrations commonly detected within the Delta during dry conditions. Fifty-percent static renewals were conducted daily. There was a total of eight replicates per each treatment group, with one fish per tank. Water samples were periodically collected throughout the waterborne exposures to measure bifenthrin concentrations.

Following a two-week waterborne exposure, juvenile rainbow trout were euthanized in sodium bicarbonate buffered MS-222 (Sigma-Alrich, St. Louis, MO, USA). Total length $(\mathrm{cm})$ and weight $(\mathrm{g})$ were taken and whole brains were extracted and either flash frozen in liquid nitrogen and stored at $-80^{\circ} \mathrm{C}$ for downstream RNA sequencing analysis $(n=4$ per treatment group) or placed in Bouin's solution ( $n=4$ per treatment group; SigmaAlrich, St. Louis, MO, USA) for histological assessment. The current experiment was performed ethically and in accordance with protocol \#20130010 approved by the University of California, Riverside Institutional Animal Care and Use Committee.

\subsection{Bifenthrin Extractions and Analysis}

Water samples collected (in duplicate, $1 \mathrm{~L}$ samples) from exposure tanks after 24 hours (h), 7 days (d), and $14 \mathrm{~d}$ were stored at $4{ }^{\circ} \mathrm{C}$ in amber glass bottles and extracted within two weeks following initial sample collection by liquid-liquid extraction. Bifenthrin extractions were conducted as previously reported [22]. Samples were analyzed using an Agilent gas chromatograph (6850A) and mass spectrometer (5975C; Santa Clara, CA, USA) in methane negative ionization mode. Samples were injected $(2 \mu \mathrm{L})$ in pulsed $\left(3.4 \times 10^{5} \mathrm{~Pa}\right)$ splitless mode at $260{ }^{\circ} \mathrm{C}$ onto an HP5 MS column $(30 \mathrm{~m} \times 250 \mu \mathrm{m}, 0.25 \mu \mathrm{m})$. Compounds were separated using helium carrier gas $(1 \mathrm{~mL} / \mathrm{min}$, constant flow $)$ and the following oven program: $50{ }^{\circ} \mathrm{C}$ initial temperature, ramp to $200{ }^{\circ} \mathrm{C}$ at $20{ }^{\circ} \mathrm{C} / \mathrm{min}$, followed by a ramp to $295^{\circ} \mathrm{C}$ at $10{ }^{\circ} \mathrm{C} / \mathrm{min}$, with $10 \mathrm{~min}$ hold. Selected ion detection mode was used and the MS temperatures were: $300{ }^{\circ} \mathrm{C}$ transferline, $150{ }^{\circ} \mathrm{C}$ source, and $150{ }^{\circ} \mathrm{C}$ quadrupole. Chemstation software (Santa Clara, CA, USA; version F.01.03.2357) was used to identify and quantify the samples. The responses were calibrated using standards $(0.5,1.0,2.0,5.0$, $10,50,100,150,200,250 \mathrm{ng} / \mathrm{mL}$ in $9: 1$ hexane:acetone) fit to a quadratic equation $\left(\mathrm{r}^{2}>0.999\right.$ for bifenthrin and recovery surrogate decachlorobiphenyl (DCBP)) using internal standard quantification $\left({ }^{13} \mathrm{C}_{12}\right.$-DCBP and $\mathrm{D}_{6}$-bifenthrin). A calibration curve was assessed using a $50 \mathrm{ng} / \mathrm{mL}$ standard once every eight samples ( $<10 \%$ difference). DCBP and bifenthrin were positively identified by retention time $(<0.1 \%$ difference in comparison to standard) and by the peak area ratios of the quantification and qualifier ion (498 and $500 \mathrm{~m} / z$ for DCBP, 386, 387, and $241 \mathrm{~m} / z$ for bifenthrin, $<20 \%$ difference in comparison to standard). The MDL for bifenthrin was $0.5 \mathrm{ng} / \mathrm{L}$ and reporting limit was $2 \mathrm{ng} / \mathrm{L}$.

\subsection{RNA Isolation, Preparation, and Sequencing}

Juvenile rainbow trout brains ( $n=4$ per exposure treatment) were flash frozen and stored at $-80^{\circ} \mathrm{C}$ until RNA extractions. A tissue homogenizer (Omni International, Kennesaw, GA, USA) was used to homogenize whole brain samples and total RNA extracted with an RNeasy Mini Kit (Qiagen, Valencia, CA, USA). The RNA concentrations were determined using a Nanodrop-2000c (Thermo Fisher Scientific, Waltham, MA, USA) with RNA quality and integrity assessed on an Agilent 2100 Bioanalyzer chip. All samples used for downstream library preparation had high-quality RNA Integrity Numbers (RIN > 9). RNA was diluted to $1 \mu \mathrm{g}$ per sample, placed on dry ice, and sent to Novogene 
(Sacramento, CA, USA) for library preparation and sequencing analysis. Sequencing libraries were generated using a NEBNext Ultra Library Prep Kit for Illumina (New England Biolabs, Ipswich, MA, USA), following manufacturer's recommendations. An Agilent Bioanalyzer 2100 system was used to assess library quality. The clustering of index-coded samples was performed on a cBot Cluster Generation System using the PE Cluster cBotHS Kit (Illumina, San Diego, CA, USA). Subsequent, paired-end, 150 bp sequencing was performed by Novogene. Raw reads were submitted to the NCBI SRA database (accession: PRJNA694644).

\subsection{Transcriptome Assembly and Functional Annotation}

To remove Illumina adapter sequences and filter out poor quality reads from raw read data, fastp (version 0.20.0) was used. All downstream analyses were based on cleaned, trimmed reads. HISAT2 (version 2.0.5) was used to map all pooled, trimmed reads to the rainbow trout reference genome (GCF_002163495.1_Omyk_1.0_genomic.gtf). For novel gene prediction, StringTie (version 1.3.3) and GffCompare (version 0.10.6) were used to assemble the set of transcript isoforms of each bam file obtained from the mapping step and compare StringTie assemblies to the rainbow trout reference annotation file to sort out novel genes from known ones. FeatureCounts (version 1.5.0-p3) was used to count the read numbers that were mapped to each gene. Reads Per Kilobase of exon model per Million mapped reads (RPKM) of each gene was calculated based on gene length and read count. Differential expression quantification was generated using DESeq2 (version 1.20.0) at $p<0.05$ following Benjamini-Hochberg's false discovery rate correction (FDR) [35]. ClusterProfiler (version 3.24.3) was used for functional annotation in Gene Ontology (GO) and Kyoto Encyclopedia of Genes and Genomes (KEGG) Pathway enrichment analyses at a significance of FDR $<0.05$. Significant, differentially expressed genes (DEGs) were uploaded to Ingenuity Pathway Analysis (IPA; Qiagen; Valencia, CA, USA) to generate predicted canonical, disease and function, and network relationships between treatment groups.

\subsection{Quantitative Polymerase Chain Reaction ( $q P C R$ ) Validation of Differentially Expressed Genes}

To validate expression profiles of DEGs determined from RNA sequencing analysis, qPCR was conducted on select genes involved in the top predicted pathways altered following bifenthrin treatment. RNA was diluted to $1 \mu \mathrm{g}$ and reverse transcribed to cDNA using an iScript Reverse Transcription Supermix kit (Bio-Rad, Hercules, CA, USA). To perform qPCR, a $20 \mu \mathrm{L}$ reaction was performed, with an input concentration of $100 \mathrm{ng}$ cDNA and $10 \mu \mathrm{M}$ of primer pairs (csf1, cbs, ptafr, and mtap; Supplementary Table S1). All qPCR reactions were conducted in triplicate and run on a Bio-Rad CFX Connect Real-Time PCR Detection System and followed the same thermal cycling conditions as previously described [23]. To determine expression fold change between treatment and control groups, $2^{-\Delta \Delta \mathrm{Ct}}$ was used [36], with all results normalized to the housekeeping gene, ef1 $\alpha$, as no significant difference in expression was observed between treatments.

\subsection{Histopathological Analysis}

Rainbow trout brains were fixed in Bouin's solution for $24 \mathrm{~h}$, transferred to $70 \%$ ethanol, and sent to HistoWiz (Brooklyn, NY, USA) for sectioning and tissue staining. Sagittal sections of each brain, $5 \mu \mathrm{m}$ sections, were taken in triplicate on each slide, with a total of four biological replicates per exposure treatment $(n=4)$. Each brain section underwent a terminal deoxynucleotidyl transferase dUTP nick end labeling (TUNEL) stain to detect apoptosis from fragmentation of DNA strand breaks. Apoptotic cells were identified by the presence of brown staining, manually counted in the cerebellum and optic tectum regions, and quantified by the number of TUNEL positive cells per $1 \mathrm{~mm}^{2}$ area. 


\section{Results}

\subsection{Waterborne Bifenthrin Concentrations}

The mean concentrations of bifenthrin in the control treatment group throughout the duration of the exposures were below the reporting limit $(<2 \mathrm{ng} / \mathrm{L}$; Supplementary Table S2). The mean \pm standard deviation concentration of the nominal $15 \mathrm{ng} / \mathrm{L}$ bifenthrin treatment from $24 \mathrm{~h}, 7 \mathrm{~d}$, and $14 \mathrm{~d}$ was $12.82 \pm 2.23,8.78 \pm 1.04$, and $6.26 \pm 1.15 \mathrm{ng} / \mathrm{L}$, respectively. The mean percent DCBP surrogate recovery was $86.74 \pm 4.16,40.55 \pm 6.49$, and $21.04 \pm 0.65 \%$, respectively. The mean concentration of the nominal $30 \mathrm{ng} / \mathrm{L}$ bifenthrin treatment from $24 \mathrm{~h}, 7 \mathrm{~d}$, and $14 \mathrm{~d}$ was $21.68 \pm 0.004,30.66 \pm 7.72$, and $12.88 \pm 1.94 \mathrm{ng} / \mathrm{L}$, respectively. The mean percent DCBP surrogate recovery was $90.21 \pm 0.61,60.9 \pm 17.73$, and $18.05 \pm 4.37 \%$, respectively (Supplementary Table S2).

\subsection{Transcriptome Assembly and Annotation}

A total of 530,790,834 mapped reads were generated from rainbow trout, with $306,265,598$ bases assembled following adapter trimming ( 25.5 million/replicate) and used in transcriptome assembly (Supplementary Table S3). More than $86 \%$ of the reads aligned to the transcriptome using HISAT2, indicating a representative transcriptome assembly. There were 21 significantly, differentially expressed genes (DEGs) in the $15 \mathrm{ng} / \mathrm{L}$ bifenthrin treatment group and 131 DEGs in the $30 \mathrm{ng} / \mathrm{L}$ bifenthrin treatment group, relative to controls (FDR < 0.05; Supplementary Figure S1). Additionally, there were 43 DEGs between the 15 and $30 \mathrm{ng} / \mathrm{L}$ treatment groups. A heatmap dendrogram depicts DEGs strongly clustered between treatment groups (Figure 1).

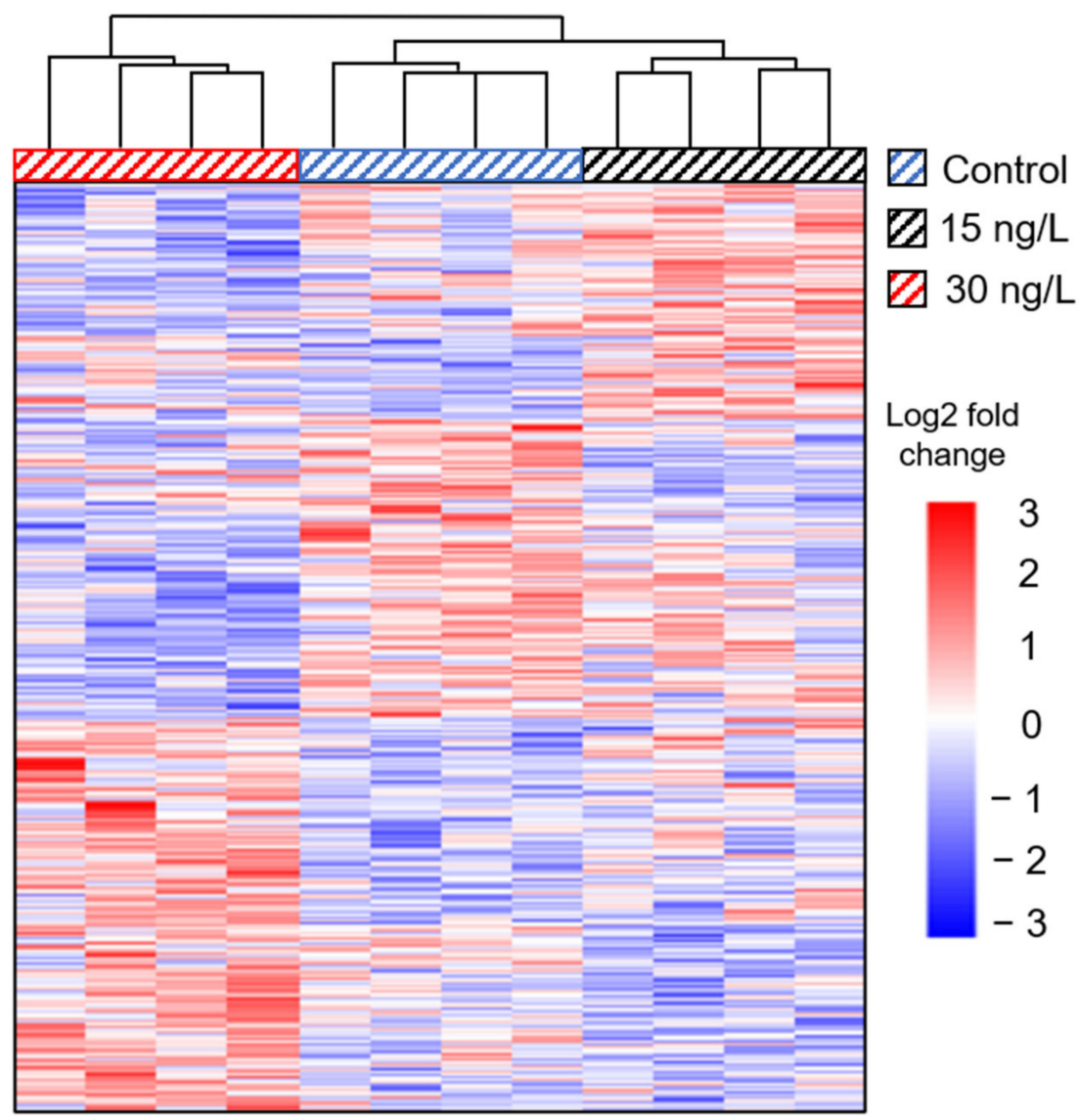

Figure 1. Heatmap dendrogram comparing differentially expressed genes (DEGs) in the brains of juvenile rainbow trout exposed to 0,15 , and $30 \mathrm{ng} / \mathrm{L}$ bifenthrin. 
Gene ontology (GO) molecular processes involved in ferric iron binding (ferritin), iron binding (ferritin), and nucleic acid binding transcription (transcription factor jun-D, nuclear hormone receptor HR38, proto-oncogene c-Fos), sequence-specific DNA binding transcription (transcription factor jun-D, nuclear hormone receptor HR38, proto-oncogene c-Fos), and neuropeptide hormone activity (isotocin-neurophysin IT 2) were significantly altered in trout exposed to $15 \mathrm{ng} / \mathrm{L}$ bifenthrin, relative to controls (Figure 2A). Homeostatic pathways including cellular iron ion, iron ion, cellular cation, and chemical homeostasis were among the top ten altered GO biological function pathways in trout exposed to $15 \mathrm{ng} / \mathrm{L}$ bifenthrin (Supplementary Table S4). Within the top five KEGG pathways, GnRH and apelin signaling pathways were significantly dysregulated in trout exposed to $15 \mathrm{ng} / \mathrm{L}$ bifenthrin (Figure 2B, Supplementary Table S5). The extracellular matrix structural constituent (collagen alpha-1(I) chain), nucleic acid binding transcription factor, sequence-specific DNA binding transcription, and lipid transporter activity pathways were among the top GO molecular processes altered following exposure to $30 \mathrm{ng} / \mathrm{L}$ bifenthrin (Figure 2A, Supplementary Table S4), though ECM structural constituent was the only significantly altered GO pathway following treatment (Figure 2C, Supplementary Table S4). Similarly, ECM-receptor interaction and focal adhesion were the top two KEGG pathways significantly altered in rainbow trout exposed to $30 \mathrm{ng} / \mathrm{L}$ bifenthrin, relative to controls (Figure 2D, Supplementary Table S5).

A

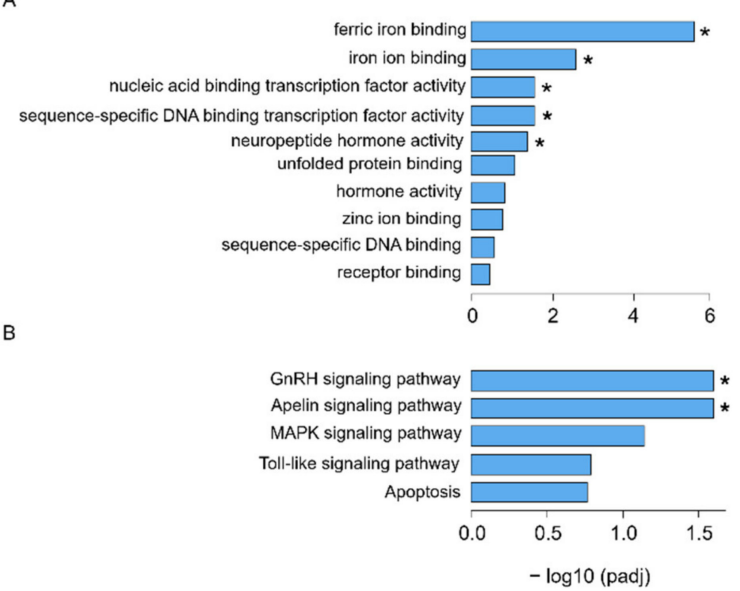

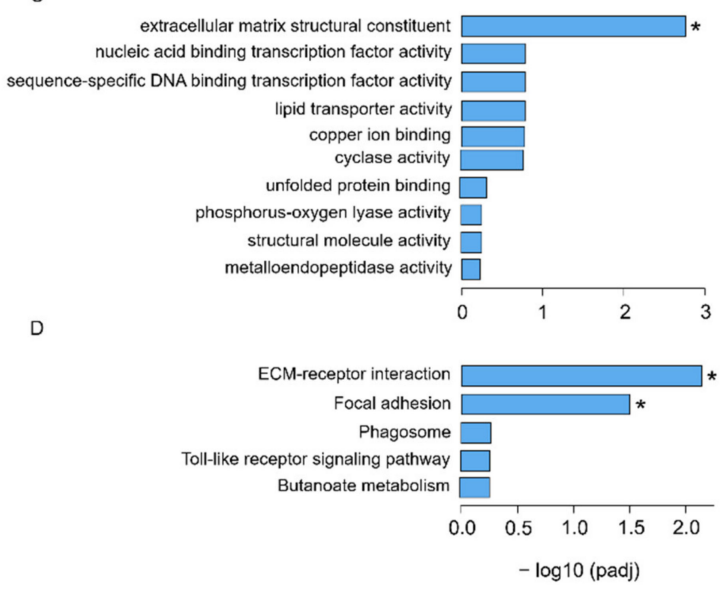

Figure 2. Top GO molecular function (MF) pathways in the brains of juvenile rainbow trout exposed to (A) $15 \mathrm{ng} / \mathrm{L}$ and (C) $30 \mathrm{ng} / \mathrm{L}$ bifenthrin, and KEGG pathways from trout exposed to (B) $15 \mathrm{ng} / \mathrm{L}$ and (D) $30 \mathrm{ng} / \mathrm{L}$ bifenthrin. The asterisks denote statistically significantly differences between exposure treatment groups and controls (FDR < 0.05$)$.

The top diseases and functions predicted in IPA in rainbow trout exposed to $15 \mathrm{ng} / \mathrm{L}$ were involved in cell-to-cell signaling and interaction, cellular compromise, organismal injury and abnormalities, cellular development, and cell death and survival (Supplementary Table S6). Among the top 10 predicted canonical pathways affected in the low, $15 \mathrm{ng} / \mathrm{L}$ treatment group were associated with $S$-methyl-5'-thioadenosine degradation II, histidine degradation III and IV, and coagulation system (Supplementary Figure S2). The top altered network was involved in cell-to-cell signaling and interaction, cellular movement, and immune cell trafficking, with a score of 22 and 9 DEGs involved (Supplementary Figure S3). Organismal injury and abnormalities, tissue morphology, hematological disease, molecular transport, cell-to-cell signaling and interaction, and reproductive system development and function were among the top 15 diseases and functions predicted to be altered in the brains of rainbow trout exposed to $30 \mathrm{ng} / \mathrm{L}$ (Supplementary Table S6). The top predicted canonical pathways in the $30 \mathrm{ng} / \mathrm{L}$ treatment group were involved in S-methyl-5'-thioadenosine degradation II, cysteine biosynthesis/homocysteine degradation, neuroprotective role of THOP1 in Alzheimer's disease, extrinsic prothrombin activation pathway, and coagulation system (Supplementary Figure S2). The top altered network was involved in cell cycle, cell-to-cell signaling and interaction, and cellular compromise, with a score of 29 and 12 DEGs involved (Supplementary Figure S4). 


\section{3. qPCR Validation}

A subset of genes (csf1, cbs, ptafr, and mtap) determined to be differentially expressed following RNA sequencing were verified by qPCR. The expression fold change of csf 1 (1.19), cbs (1.11), ptafr (1.96), and mtap (-1.01) following RNA sequencing exhibited similar fold change expression relationships determined by qPCR, csf1 (1.26), cbs (1.16), ptafr (1.49), and mtap (-0.90), which confirmed expression patterns (Supplementary Figure S5).

\subsection{TUNEL Positive, Apoptotic Cell Assessment}

Rainbow trout exposed to 15 and $30 \mathrm{ng} / \mathrm{L}$ bifenthrin had significantly increased numbers of TUNEL positive, apoptotic cells in the cerebellum, relative to control $(p=0.045$ and $p=0.008$, respectively; Figure $3 \mathrm{~A}, \mathrm{~B})$. Trout exposed to $30 \mathrm{ng} / \mathrm{L}$ bifenthrin exhibited a significantly increased number of apoptotic cells in the optic tectum $(p=0.026$; Figure $3 \mathrm{~A}, \mathrm{C})$, though not in trout exposed to $15 \mathrm{ng} / \mathrm{L}$ bifenthrin ( $p=0.100$; Figure $3 \mathrm{C}$ ).

A

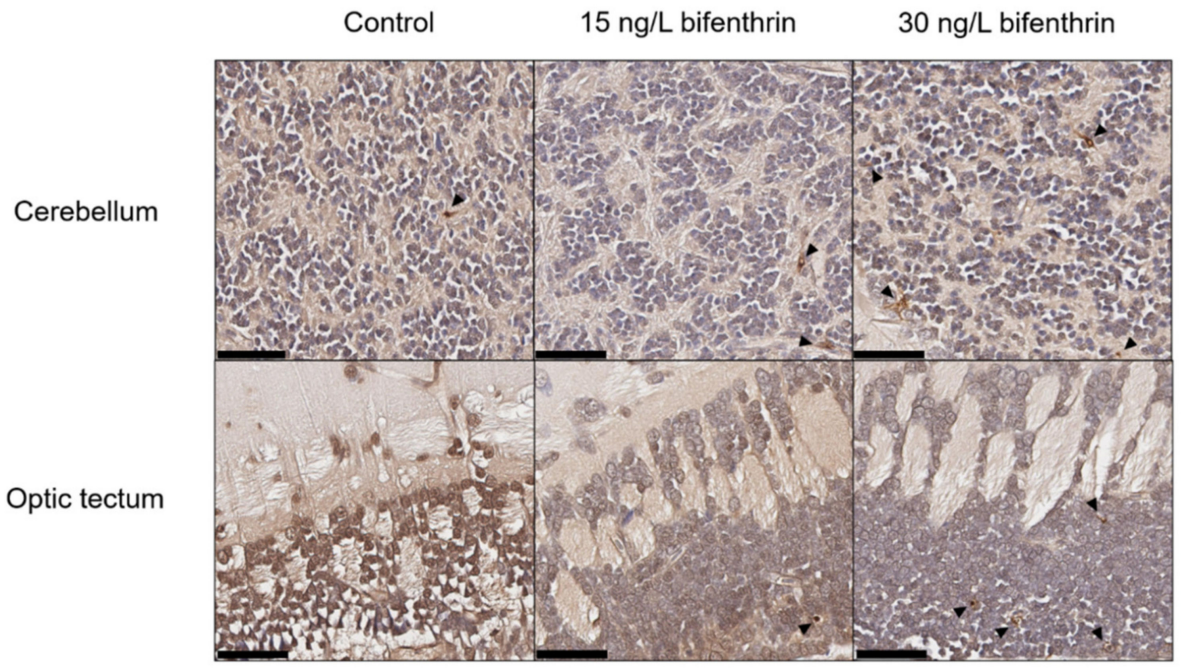

B

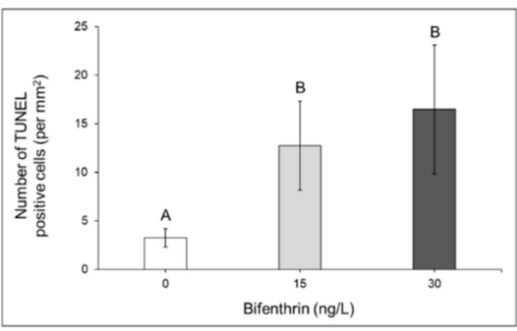

C

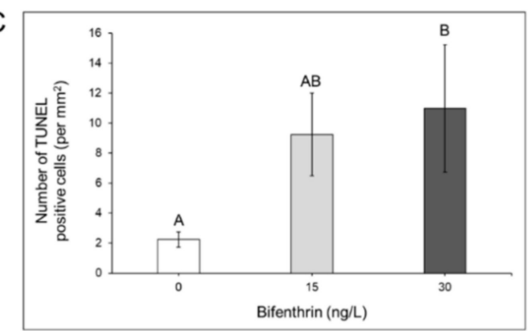

Figure 3. TUNEL positive cells assessed in the $(\mathbf{A}, \mathbf{B})$ cerebellum and $(\mathbf{A}, \mathbf{C})$ optic tectum of juvenile rainbow trout exposed to 0,15 , and $30 \mathrm{ng} / \mathrm{L}$ bifenthrin. TUNEL positive cells were quantified by the number of brown-stained nuclei per $1 \mathrm{~mm}^{2}$, denoted by dark arrows, and black bars represent a $50 \mu \mathrm{M}$ scale bar (A). Treatments with different uppercase letters are representative of statistically significant treatments from other treatment groups $(p<0.05)$.

\section{Discussion}

Transcriptomic profiles were determined in the brains of rainbow trout, a surrogate to the critically endangered steelhead trout in California, following a two-week bifenthrin treatment to concentrations frequently measured within water samples $(\leq 30 \mathrm{ng} / \mathrm{L})$ from the Sacramento-San Joaquin Delta. Significantly altered DEGs were incorporated into multiple functional annotation tools (GO, KEGG, and IPA), with genes involved in the top predicted pathways further validated using qPCR. Histopathological assessment was conducted in the brain and TUNEL-positive cells were identified in the cerebellum and optic tectum of exposed fish, as apoptotic-associated pathways were recently shown to be the top predicted pathways impaired in both steelhead trout and Chinook salmon following bifenthrin treatment for two-week and $96 \mathrm{~h}$ durations, respectively $[23,24]$, using non-targeted metabolomics. 
KEGG pathway analyses involved in GnRH signaling were the top significantly altered functional pathways impaired in the brains of trout exposed to $15 \mathrm{ng} / \mathrm{L}$ bifenthrin ( $p$-adj $=2.55 \times 10^{-2}$ ), based on the decrease of egr1. Egr1, early growth response protein 1, is within the immediate early gene (IEG) family [37] and considered a primary response gene due to its rapid response to changes in GnRH expression [38,39], with a positive increased correlation between the induction of egr1 expression relative to the concentration of GnRH [39]. The dysregulation of GnRH expression has previously been observed in the brains of rainbow trout following a $96 \mathrm{~h}$ and two-week exposure to 1.5 and $0.15 \mu \mathrm{g} / \mathrm{L}$ bifenthrin, respectively [20], as well as in Chinook salmon exposed to $1.5 \mu \mathrm{g} / \mathrm{L}$ bifenthrin for $96 \mathrm{~h} \mathrm{[21].} \mathrm{Our} \mathrm{results} \mathrm{indicate} \mathrm{that} \mathrm{altered} \mathrm{expression} \mathrm{changes} \mathrm{of} \mathrm{genes} \mathrm{involved} \mathrm{in}$ the dopaminergic pathway are impaired in salmonids even at low $\mathrm{ng} / \mathrm{L}$ concentrations following bifenthrin exposure and suggests that changes to this pathway are among the most sensitive to juvenile salmonids.

The top GO molecular function pathways affected in the $15 \mathrm{ng} / \mathrm{L}$ bifenthrin treatment were related to ferric iron binding $\left(p\right.$-adj $\left.=2.48 \times 10^{-6}\right)$, based on the upregulation of ferritin, and nucleic acid binding transcription factor activity ( $p$-adj $=2.50 \times 10^{-2}$ ), based on the dysregulation of $j u n-D, H R 38$, and $c$-Fos. Ferritin is an iron storage protein that is predominantly expressed within oligodendrocytes, astrocytes, and microglia in the brain, with a predominant role in the intracellular homeostatic balance of iron [40,41]. Improper mRNA ferritin expression can induce oxidative stress, induce inflammatory responses, and impact cell survival $[42,43]$.

The expression of jun-D, a dysregulated gene involved in proper nucleic acid binding transcription in rainbow trout exposed to bifenthrin, also serves as a transcriptional regulator of ferritin from electrophilic xenobiotics and oxidative stress [43] and was significantly increased in trout following $15 \mathrm{ng} / \mathrm{L}$ bifenthrin exposure. Oxidative stress, respiration, and iron binding functional annotation pathways comprised $6 \%$ of the DEGs in juvenile delta smelt (Hypomesus transpacificus) exposed to 0.0625 and $0.125 \mu \mathrm{g} / \mathrm{L}$ esfenvalerate [44] and cellular iron ion homeostasis was among the top GO pathways affected in larval delta smelt exposed to $4.84 \mu \mathrm{g} / \mathrm{L}$ permethrin for $96 \mathrm{~h}$ [45]. Furthermore, altered iron homeostasis can induce oxidative stress and generate reactive oxygen species [46], which was recently shown to be involved in the inflammatory pathway of steelhead exposed to $120 \mathrm{ng} / \mathrm{L}$ bifenthrin [23]. This suggests that dysregulated iron homeostatic pathways may be a general indicator of pyrethroid exposure [45] and subsequently impair neuronal cell structure.

The extracellular matrix structural constituent GO pathway was significantly altered in trout exposed to $30 \mathrm{ng} / \mathrm{L}$ bifenthrin $\left(p\right.$-adj $\left.=1.72 \times 10^{-3}\right)$, based on the dysregulation of col1a1, col1a2, and col1a3. The expression of two of these extracellular matrix structural collagens, col1a2 and colla1, were previously reported to be inhibited in larval delta smelt exposed to $4.84 \mu \mathrm{g} / \mathrm{L}$ permethrin for $96 \mathrm{~h}$ [45]. Interestingly, a transcriptomic and proteomic-based study conducted on the hypothalamus of largemouth bass (Micropterus salmoides) following a dietary exposure to $3 \mathrm{mg}$ dieldrin $/ \mathrm{kg}$ noted changes in col1a1 mRNA expression, as well as Colla protein levels [47]. Impaired structural integrity of the extracellular matrix and associated proteins that play important roles in cell structure may induce underlying apoptotic effects in the brains of fish following pyrethroid exposure, as previously suggested with dieldrin [47].

Cell-to-cell signaling, cellular compromise, and cell death and survival were among the top predicted disease and function pathways impaired in the brains of rainbow trout exposed to 15 and $30 \mathrm{ng} / \mathrm{L}$ bifenthrin, determined by IPA, further supporting altered GO pathways. The functional annotations were related to impaired cell attachment, disorganization of cytoskeleton, and apoptosis of macrophage precursor cells. Juvenile steelhead exposed to higher concentrations of bifenthrin, 60 and $120 \mathrm{ng} / \mathrm{L}$, were recently shown to have altered molecular and cellular functions including cellular compromise and cell signaling pathways, respectively [23]. Impacts to GO biological processes related to cellular signaling were impaired in embryonic zebrafish exposed to $40 \mu \mathrm{g} / \mathrm{L}$ deltamethrin [48], with top pathways involved in neuronal systems and cell-to-cell adhesion and signaling. 
Additionally, altered expression of a cell adhesion protein found in the extracellular matrix was dysregulated in larval delta smelt exposed to $<2 \mu \mathrm{g} / \mathrm{L}$ permethrin [45]. These findings support the top altered KEGG pathways in rainbow trout exposed to $30 \mathrm{ng} / \mathrm{L}$ bifenthrin, with impaired focal adhesion, suggesting a potential relationship between downstream effects of dysregulated iron homeostatic pathways and structural integrity of cell attachment sites and extracellular matrix, though further study is needed to support this interrelationship and influence on apoptotic alterations.

The top predicted disease and function pathways in IPA included cell death and survival in bifenthrin-exposed rainbow trout. Similar pathways were previously observed in the brains of juvenile steelhead treated with $60 \mathrm{ng} / \mathrm{L}$ bifenthrin [23] and Chinook exposed to $150 \mathrm{ng} / \mathrm{L}$ bifenthrin [24] when assessed for metabolomic profile changes. There was a significantly increased incidence of TUNEL positive cells in the cerebellum of 15 and $30 \mathrm{ng} / \mathrm{L}$ bifenthrin-exposed rainbow trout and a significant increase in the optic tectum of $30 \mathrm{ng} / \mathrm{L}$ bifenthrin-exposed trout, which validates predicted metabolomic [23,24] and transcriptomic-level apoptotic pathways. The endangered fish mahseer (Tor putitora) exposed to $63 \mu \mathrm{g} / \mathrm{L}$ cypermethrin for $96 \mathrm{~h} \mathrm{[49]} \mathrm{and} \mathrm{silver} \mathrm{carp} \mathrm{(Hypophthalmichtys} \mathrm{molitrix)}$ exposed to $2 \mu \mathrm{g} / \mathrm{L}$ deltamethrin for $96 \mathrm{~h} \mathrm{[50]} \mathrm{also} \mathrm{exhibited} \mathrm{histopathological} \mathrm{changes} \mathrm{in} \mathrm{the}$ brain, including observed neuronal degeneration, infiltration, and spongiosis. However, this is the first known study that quantitatively assessed neuronal apoptotic histopathological effects in fish following bifenthrin treatment.

Dysregulated pathways involved in maintaining structural stability of the extracellular matrix and impaired focal adhesion in the brains of bifenthrin-exposed trout are consistent with oxidative stress induced effects previously observed in neuronal in vitro cell lines and in murine, in vivo-based studies, following bifenthrin treatment [51-54], though, interestingly, oxidative stress genes were not differentially altered in bifenthrin treatment groups, relative to controls. Similarly, we previously reported that steelhead trout exposed to 60 and $120 \mathrm{ng} / \mathrm{L}$ bifenthrin were predicted to have induced reactive oxygen species production due to oxidative stress, and subsequently observed apoptotic effects driven by altered levels of metabolites [23]. Increased apoptotic cells were observed in bifenthrin-exposed trout, determined histopathologically, and KEGG predicted apoptotic pathways at $p=0.057$ in rainbow trout exposed to $30 \mathrm{ng} / \mathrm{L}$ bifenthrin in the current transcriptomics-based study. It is possible that the predicted ECM and apoptotic pathways occurred as an acute phase response, which may explain the relatively weak transcriptomic relationship due to the duration of the response. Overall, there were relatively few differentially expressed genes following annotation relative to the number of altered metabolites previously identified [23,24], which has also been observed by others [55]. Additionally, concentrations of bifenthrin that steelhead were previously exposed to, 60 and $120 \mathrm{ng} / \mathrm{L}$, were likely high enough to induce transcriptomic level changes from altered metabolite levels. Furthermore, the steelhead previously assessed were significantly smaller than the current rainbow trout, which could influence the sensitivity to bifenthrin, as well as the rate of metabolism. To better characterize the mechanistic effects of bifenthrin, combining several omic-level responses within the same species and life stage, while utilizing the same exposure concentrations, would be beneficial to understand the interrelationship between molecular, histological, and behavioral-level effects.

\section{Conclusions}

Juvenile rainbow trout exposed to environmentally relevant concentrations of bifenthrin exhibited transcriptomic-level changes and histopathological alterations throughout the cerebellum and optic tectum, as determined by increased TUNEL positive cells. This is the first known study to report neurotoxic effects of bifenthrin at low $\mathrm{ng} / \mathrm{L}$ concentrations and subsequent histopathological insult to brain structure. Additional studies focused on region-specific areas of the brain where dysregulated iron homeostasis and impaired cell structure are predominantly occurring are warranted to better characterize the neurotoxic effect of bifenthrin. Furthermore, integrating multiple 'omic-based approaches using 
functional annotation networks would provide a clearer depiction of bifenthrin's mode of action and the influence of species, life stage, and concentration to neurotoxic responses, which could be used in ecological risk assessment decisions.

Supplementary Materials: The following are available online at https:/ /www.mdpi.com/2305-6 304/9/3/48/s1, Figure S1: Volcano plots of differentially expressed genes (DEGs) between control and $15 \mathrm{ng} / \mathrm{L}$ (A), control and $30 \mathrm{ng} / \mathrm{L}$ (B), and 15 and $30 \mathrm{ng} / \mathrm{L}$ bifenthrin (C) treatment groups. Upregulated genes are depicted in red, downregulated genes depicted in green, and those not significanlty different depicted in blue (FDR $<0.05)$. Figure S2: Top predicted Ingenuity Pathway Analysis (IPA) canonical pathways for juvenile rainbow trout treated with (A) 15 and (B) $20 \mathrm{ng} / \mathrm{L}$ bifenthrin. Figure S3: Top predicted Ingenuity Pathway Analysis (IPA) network involved in cell-tocell signaling and interaction, cellular movement, and immune cell trafficking in juvenile rainbow trout exposed to $15 \mathrm{ng} / \mathrm{L}$ bifenthrin. Figure S4: Top predicted Ingenuity Pathway Analysis (IPA) network involved in cell cycle, cell-to-cell signaling and interaction, and cellular compromise in juvenile rainbow trout exposed to $30 \mathrm{ng} / \mathrm{L}$ bifenthrin. Figure S5: Comparison between differentially expressed genes determined by RNA sequencing and qPCR expression fold change patterns in the brains of bifenthrin-exposed rainbow trout (mean \pm SD, One-way ANOVA, Tukey's post hoc $(p<0.05)$ ). Table S1: Primer pair sequences used for qPCR validation. Table S2: Mean bifenthrin concentration \pm standard deviation (SD) in extract following a 24 hour (h), 7 day (d), and $14 \mathrm{~d}$ treatment. Mean percent recoveries are based on decachlorobiphenyl surrogate standards. Corrected mean bifenthrin concentrations in parentheses. Table S3: Total number of raw and clean RNA sequencing reads. Table S4: Top 10 gene ontology (GO) biological pathways (BP) and molecular functions (MF) impaired in juvenile rainbow trout exposed to 15 and $30 \mathrm{ng} / \mathrm{L}$ bifenthrin. Table S5: Top 5 KEGG pathways impaired in juvenile rainbow trout exposed to 15 and $30 \mathrm{ng} / \mathrm{L}$ bifenthrin. Table S6: Top 20 diseases and functions predicted in Ingenuity Pathway Analysis in rainbow trout exposed to 15 and $30 \mathrm{ng} / \mathrm{L}$ bifenthrin.

Author Contributions: J.T.M., Conceptualization, Formal Analysis, Investigation, Writing-Original Draft Preparation; K.E.H.H., Formal Analysis, Investigation, Writing—Review \& Editing; C.A.F., Formal Analysis, Investigation; M.J.L., Writing—Review \& Editing, Resources; D.S., Conceptualization, Software, Writing - Review \& Editing, Supervision, Funding Acquisition. All authors have read and agreed to the published version of the manuscript.

Funding: This research was funded through the California Department of Fish and Wildlife Proposition 1 Restoration Grant Program (\#P1896015).

Institutional Review Board Statement: This study was performed ethically and in accordance with protocol \# 20130010 approved by the University of California, Riverside Institutional Animal Care and Use Committee. Date of approval: 24 May 2019.

Data Availability Statement: The data presented in this study are available on request from the corresponding author.

Conflicts of Interest: The authors declare no conflict of interest.

\section{References}

1. Spurlock, F.; Lee, M. Synthetic Pyrethroid Use Patterns, Properties, and Environmental Effects. In Synthetic Pyrethroids: Occurrence and Behavior in Aquatic Environments; Gan, J., Spurlock, F., Hendley, P., Weston, D.P., Eds.; American Chemical Society: Washington, DC, USA, 2008; pp. 3-25.

2. Zhang, W. Global Pesticide Use: Profile, Trend, Cost/Benefit and More. Proc. Natl. Acad. Sci. USA 2018, 8, 1-27.

3. Li, H.; Cheng, F.; Wei, Y.; Lydy, M.J.; You, J. Global Occurrence of Pyrethroid Insecticides in Sediment and the Associated Toxicological Effects on Benthic Invertebrates: An Overview. J. Hazard. Mater. 2017, 324, 258-271. [CrossRef] [PubMed]

4. Tang, W.; Wang, D.; Wang, J.; Wu, Z.; Li, L.; Huang, M.; Xu, S.; Yan, D. Pyrethroid Pesticide Residues in the Global Environment: An Overview. Chemosphere 2018, 191, 990-1007. [CrossRef]

5. Bradbury, S.P.; Coats, J.R. Comparative Toxicology of the Pyrethroid Insecticides. In Reviews of Environmental Contamination and Toxicology; Ware, G.W., Ed.; Springer: New York, NY, USA, 1989; Volume 108, pp. 133-177.

6. Stehle, S.; Schulz, R. Agricultural Insecticides Threaten Surface Waters at the Global Scale. Proc. Natl. Acad. Sci. USA 2015, 112, 5750-5755. [CrossRef]

7. Budd, R.; Wang, D.; Ensminger, M.; Phillips, B. An Evaluation of Temporal and Spatial Trends of Pyrethroid Concentrations in California Surface Waters. Sci. Total Environ. 2020, 718, 137402. [CrossRef] [PubMed] 
8. Weston, D.P.; Holmes, R.W.; Lydy, M.J. Residential Runoff as a Source of Pyrethroid Pesticides to Urban Creeks. Environ. Pollut. 2009, 157, 287-294. [CrossRef]

9. Sanders, C.J.; Orlando, J.L.; Hladik, M.L. Detections of Current-Use Pesticides at 12 Surface Water Sites in California during a 2-Year Period Beginning in 2015: U.S. Geological Survey Data Series 1088; U.S. Geological Survey: Reston, VA, USA, 2018 ; p. 40.

10. Weston, D.P.; Lydy, M.J. Urban and Agricultural Sources of Pyrethroid Insecticides to the Sacramento-San Joaquin Delta of California. Environ. Sci. Technol. 2010, 44, 1833-1840. [CrossRef]

11. Siepmann, S.; Holm, S. Hazard Assessment of the Synthetic Pyrethroid Insecticides Bifenthrin, Cypermethrin, Esfenvalerate, and Permethrin to Aquatic Organisms in the Sacramento-San Joaquin River System; Office of Spill Prevention and Response 00-6. Administrative Report; California Department of Fish and Game: Rancho Cordova, CA, USA, 2000.

12. Buchanan, R.A.; Skalski, J.R.; Brandes, P.L.; Fuller, A. Route Use and Survival of Juvenile Chinook Salmon through the San Joaquin River Delta. N. Am. J. Fish. Manag. 2013, 33, 216-229. [CrossRef]

13. Leidy, R.A.; Becker, G.S.; Harvey, B.N. Historical Distribution and Current Status of Steelhead/Rainbow Trout (Oncorhynchus Mykiss) in Streams of the San Francisco Estuary, California; Center for Ecosystem Management and Restoration: Oakland, CA, USA, 2005.

14. Brooks, M.L.; Fleishman, E.; Brown, L.R.; Lehman, P.W.; Werner, I.; Scholz, N.; Mitchelmore, C.; Lovvorn, J.R.; Johnson, M.L.; Schlenk, D.; et al. Life Histories, Salinity Zones, and Sublethal Contributions of Contaminants to Pelagic Fish Declines Illustrated with a Case Study of San Francisco Estuary, California, USA. Estuaries Coasts 2012, 35, 603-621. [CrossRef]

15. Katz, J.; Moyle, P.B.; Quiñones, R.M.; Israel, J.; Purdy, S. Impending Extinction of Salmon, Steelhead, and Trout (Salmonidae) in California. Environ. Biol. Fishes 2013, 96, 1169-1186. [CrossRef]

16. Mills, T.J.; McEwan, D.R.; Jennings, M.R. California Salmon and Steelhead: Beyond the Crossroads. In Pacific Salmon and Their Ecosytems; Stouder, D.J., Bisson, P.A., Naiman, R.J., Eds.; Chapman and Hall: New York, NY, USA, 1997.

17. Sommer, T.; Armor, C.; Baxter, R.; Breuer, R.; Brown, L.; Chotkowski, M.; Culberson, S.; Feyrer, F.; Gingras, M.; Herbold, B.; et al. The Collapse of Pelagic Fishes in the Upper San Francisco Estuary: El Colapso de Los Peces Pelagicos En La Cabecera Del Estuario San Francisco. Fisheries 2007, 32, 270-277. [CrossRef]

18. Weston, D.P.; Schlenk, D.; Riar, N.; Lydy, M.J.; Brooks, M.L. Effects of Pyrethroid Insecticides in Urban Runoff on Chinook Salmon, Steelhead Trout, and Their Invertebrate Prey. Environ. Toxicol. Chem. 2015, 34, 649-657. [CrossRef] [PubMed]

19. De Parsia, M.; Orlando, J.L.; McWayne, M.M.; Hladik, M.L. Pesticide Inputs to the Sacramento—San Joaquin Delta, 2015-2016: Results from the Delta Regional Monitoring Program: U.S. Geological Survey Data Series 1089; U.S. Geological Survey: Reston, VA, USA, $2018 ;$ p. 49.

20. Crago, J.; Schlenk, D. The Effect of Bifenthrin on the Dopaminergic Pathway in Juvenile Rainbow Trout (Oncorhynchus mykiss). Aquat. Toxicol. 2015, 162, 66-72. [CrossRef]

21. Giroux, M.; Gan, J.; Schlenk, D. The Effects of Bifenthrin and Temperature on the Endocrinology of Juvenile Chinook Salmon. Environ. Toxicol. Chem. 2019, 38, 852-861. [CrossRef] [PubMed]

22. Giroux, M.; Vliet, S.M.F.; Volz, D.C.; Gan, J.; Schlenk, D. Mechanisms behind Interactive Effects of Temperature and Bifenthrin on the Predator Avoidance Behaviors in Parr of Chinook Salmon (Oncorhynchus tshawytscha). Aquat. Toxicol. 2019, 216, 105312. [CrossRef]

23. Magnuson, J.T.; Cryder, Z.; Andrzejczyk, N.E.; Harraka, G.; Wolf, D.C.; Gan, J.; Schlenk, D. Metabolomic Profiles in the Brains of Juvenile Steelhead (Oncorhynchus mykiss) Following Bifenthrin Treatment. Environ. Sci. Technol. 2020, 54, 12245-12253. [CrossRef]

24. Magnuson, J.T.; Giroux, M.; Cryder, Z.; Gan, J.; Schlenk, D. The Use of Non-Targeted Metabolomics to Assess the Toxicity of Bifenthrin to Juvenile Chinook Salmon (Oncorhynchus tshawytscha). Aquat. Toxicol. 2020, 224, 105518. [CrossRef]

25. Brander, S.M.; Gabler, M.K.; Fowler, N.L.; Connon, R.E.; Schlenk, D. Pyrethroid Pesticides as Endocrine Disruptors: Molecular Mechanisms in Vertebrates with a Focus on Fishes. Environ. Sci. Technol. 2016, 50, 8977-8992. [CrossRef] [PubMed]

26. Narahashi, T. Neuronal Ion Channels as the Target Sites of Insecticides. Pharmacol. Toxicol. 1996, 78, 1-14. [CrossRef]

27. Soderlund, D.M.; Clark, J.M.; Sheets, L.P.; Mullin, L.S.; Piccirillo, V.J.; Sargent, D.; Stevens, J.T.; Weiner, M.L. Mechanisms of Pyrethroid Neurotoxicity: Implications for Cumulative Risk Assessment. Toxicology 2002, 171, 3-59. [CrossRef]

28. Bertotto, B.; Richards, J.; Gan, J.; Volz, D.C.; Schlenk, D. Effects of Bifenthrin Exposure on the Estrogenic and Dopaminergic Pathways in Zebrafish Embryos and Juveniles. Environ. Toxicol. Chem. 2018, 37, 236-246. [CrossRef]

29. Bertotto, L.B.; Dasgupta, S.; Vliet, S.; Dudley, S.; Gan, J.; Volz, D.C.; Schlenk, D. Evaluation of the Estrogen Receptor Alpha as a Possible Target of Bifenthrin Effects in the Estrogenic and Dopaminergic Signaling Pathways in Zebrafish Embryos. Sci. Total Environ. 2019, 651, 2424-2431. [CrossRef]

30. Brander, S.M.; He, G.; Smalling, K.L.; Denison, M.S.; Cherr, G.N. The in Vivo Estrogenic and in Vitro Anti-Estrogenic Activity of Permethrin and Bifenthrin. Environ. Toxicol. Chem. 2012, 31, 2848-2855. [CrossRef]

31. Forsgren, K.L.; Riar, N.; Schlenk, D. The Effects of the Pyrethroid Insecticide, Bifenthrin, on Steroid Hormone Levels and Gonadal Development of Steelhead (Oncorhynchus mykiss) under Hypersaline Conditions. Gen. Comp. Endocrinol. 2013, 186, $101-107$. [CrossRef] [PubMed]

32. Wang, L.; Liu, W.; Yang, C.; Pan, Z.; Gan, J.; Xu, C.; Zhao, M.; Schlenk, D. Enantioselectivity in Estrogenic Potential and Uptake of Bifenthrin. Environ. Sci. Technol. 2007, 41, 6124-6128. [CrossRef]

33. Frank, D.F.; Miller, G.W.; Harvey, D.J.; Brander, S.M.; Geist, J.; Connon, R.E.; Lein, P.J. Bifenthrin Causes Transcriptomic Alterations in MTOR and Ryanodine Receptor-Dependent Signaling and Delayed Hyperactivity in Developing Zebrafish (Danio rerio). Aquat. Toxicol. 2018, 200, 50-61. [CrossRef] [PubMed] 
34. Frank, D.F.; Brander, S.M.; Hasenbein, S.; Harvey, D.J.; Lein, P.J.; Geist, J.; Connon, R.E. Developmental Exposure to Environmentally Relevant Concentrations of Bifenthrin Alters Transcription of MTOR and Ryanodine Receptor-Dependent Signaling Molecules and Impairs Predator Avoidance Behavior across Early Life Stages in Inland Silversides (Menidia beryllina). Aquat. Toxicol. 2019, 206, 1-13.

35. Benjamini, Y.; Hochberg, Y. Controlling the False Discovery Rate: A Practical and Powerful Approach to Multiple Testing. J. R. Stat. Soc. Ser. B 1995, 57, 289-300. [CrossRef]

36. Livak, K.J.; Schmittgen, T.D. Analysis of Relative Gene Expression Data Using Real-Time Quantitative PCR and the $2^{-\Delta \Delta C T}$ Method. Methods 2001, 25, 402-408. [CrossRef]

37. Salisbury, T.B.; Binder, A.K.; Nilson, J.H. Welcoming $\beta$-Catenin to the Gonadotropin-Releasing Hormone Transcriptional Network in Gonadotropes. Mol. Endocrinol. 2008, 22, 1295-1303. [CrossRef]

38. Wurmbach, E.; Yuen, T.; Ebersole, B.J.; Sealfon, S.C. Gonadotropin-Releasing Hormone Receptor-Coupled Gene Network Organization. J. Biol. Chem. 2001, 276, 47195-47201. [CrossRef] [PubMed]

39. Yuen, T.; Wurmbach, E.; Ebersole, B.J.; Ruf, F.; Pfeffer, R.L.; Sealfon, S.C. Coupling of GnRH Concentration and the GnRH Receptor-Activated Gene Program. Mol. Endocrinol. 2002, 16, 1145-1153. [CrossRef]

40. Rhodes, S.L.; Ritz, B. Genetics of Iron Regulation and the Possible Role of Iron in Parkinson's Disease. Neurobiol. Dis. 2008, $32,183-195$. [CrossRef]

41. Torti, F.M.; Torti, S.V. Regulation of Ferritin Genes and Protein. Blood 2002, 99, 3505-3516. [CrossRef] [PubMed]

42. Orino, K.; Lehman, L.; Tsuji, Y.; Ayaki, H.; Torti, S.V.; Torti, F.M. Ferritin and the Response to Oxidative Stress. Biochem. J. 2001, 357, 241-247. [CrossRef] [PubMed]

43. Tsuji, Y. JunD Activates Transcription of the Human Ferritin H Gene through an Antioxidant Response Element during Oxidative Stress. Oncogene 2005, 24, 7567-7578. [CrossRef]

44. Connon, R.E.; Geist, J.; Pfeiff, J.; Loguinov, A.V.; Abronzo, L.S.D.; Wintz, H.; Vulpe, C.D.; Werner, I. Linking Mechanistic and Behavioral Responses to Sublethal Esfenvalerate Exposure in the Endangered Delta Smelt; Hypomesus transpacificus (Fam. Osmeridae). BMC Genom. 2009, 10, 608-625. [CrossRef] [PubMed]

45. Jeffries, K.M.; Komoroske, L.M.; Truong, J.; Werner, I.; Hasenbein, M.; Hasenbein, S.; Fangue, N.A.; Connon, R.E. The Transcriptome-Wide Effects of Exposure to a Pyrethroid Pesticide on the Critically Endangered Delta Smelt Hypomesus transpacificus. Endanger. Species Res. 2015, 28, 43-60. [CrossRef]

46. Bogdan, A.R.; Miyazawa, M.; Hashimoto, K.; Tsuji, Y. Regulators of Iron Homeostasis: New Players in Metabolism, Cell Death, and Disease. Trends Biochem. Sci. 2016, 41, 274-286. [CrossRef]

47. Martyniuk, C.J.; Kroll, K.J.; Doperalski, N.J.; Barber, D.S.; Denslow, N.D. Genomic and Proteomic Responses to Environmentally Relevant Exposures to Eieldrin: Indicators of Neurodegeneration? Toxicol. Sci. 2010, 117, 190-199. [CrossRef]

48. Chueh, T.; Hsu, L.-S.; Kao, C.-M.; Hsu, T.-W.; Liao, H.-Y.; Wang, K.-Y.; Chen, S.C. Transcriptome Analysis of Zebrafish Embryos Exposed to Deltamethrin. Environ. Toxicol. 2016, 32, 1548-1557. [CrossRef]

49. Ullah, R.; Zuberi, A.; Naeem, M.; Ullah, S. Toxicity to Hematology and Morphology of Liver, Brain and Gills during Acute Exposure of Mahseer (Tor putitora) to Cypermethrin. Int. J. Agric. Biol. 2015, 17, 199-204.

50. Ullah, S.; Li, Z.; Arifeen, M.Z.U.; Khan, S.U.; Fahad, S. Multiple Biomarkers Based Appraisal of Deltamethrin Induced Toxicity in Silver Carp (Hypophthalmichthys molitrix). Chemosphere 2019, 214, 519-533. [CrossRef] [PubMed]

51. Gargouri, B.; Bhatia, H.S.; Bouchard, M.; Fiebich, B.L.; Fetoui, H. Inflammatory and Oxidative Mechanisms Potentiate BifenthrinInduced Neurological Alterations and Anxiety-like Behavior in Adult Rats. Toxicol. Lett. 2018, 294, 73-86. [CrossRef] [PubMed]

52. Gargouri, B.; Yousif, N.M.; Attaai, A.; Bouchard, M.; Chtourou, Y.; Fiebich, B.L.; Fetoui, H. Pyrethroid Bifenthrin Induces Oxidative Stress, Neuroinflammation, and Neuronal Damage, Associated with Cognitive and Memory Impairment in Murine Hippocampus. Neurochem. Int. 2018, 120, 121-133. [CrossRef] [PubMed]

53. Gargouri, B.; Yousif, N.M.; Bouchard, M.; Fetoui, H.; Fiebich, B.L. Inflammatory and Cytotoxic Effects of Bifenthrin in Primary Microglia and Organotypic Hippocampal Slice Cultures. J. Neuroinflamm. 2018, 15, 159. [CrossRef] [PubMed]

54. Lu, X.; Hu, F.; Ma, Y.; Wang, C.; Zhang, Y.; Zhao, M. The Role of Oxidative Stress in Enantiomer-Specific, Bifenthrin-Induced Cytotoxicity in PC12 Cells. Environ. Toxicol. 2010, 26, 271-278. [CrossRef] [PubMed]

55. Olsvik, P.A.; Aulin, M.; Samuelsen, O.B.; Hannisdal, R.; Agnalt, A.-L.; Bjørn, L.T. Whole-Animal Accumulation, Oxidative Stress, Transcriptomic and Metabolomic Responses in the Pink Shrimp (Pandalus montagui) Exposed to Teflubenzuron. J. Appl. Toxicol. 2019, 39, 485-497. [CrossRef] 